\title{
THE HISTORY OF SUSTAINABILITY AND THE CASE OF THE GLOBAL ENTREPRENEURSHIP SUMMER SCHOOL: AN INCENTIVE TO INTERNATIONAL EDUCATION
}

\author{
Cláudio Antônio Klaus Júnior 1, Joel Cezar Bonin 2, Levi Hülse ${ }^{3}$, Adelcio Machado dos \\ Santos 4 , Joel Haroldo Baade ${ }^{*}$ 区 \\ ${ }^{1}$ Law Course, Alto Vale do Rio do Peixe University, Brazil \\ 2 Postgraduate Program in Basic Education, Alto Vale do Rio do Peixe University, Brazil \\ 3, 4, 5 Postgraduate Programs in Development and Society and Education, Alto Vale do Rio do Peixe \\ University, Brazil
}

DOI: https://doi.org/10.29121/granthaalayah.v8.i5.2020.195

Article Type: Case Study

Article Citation: Cláudio Antônio Klaus Júnior, Joel Cezar Bonin, Levi Hülse, Adelcio Machado dos Santos, and Joel Haroldo Baade. (2020).

THE HISTORY OF SUSTAINABILITY AND THE CASE OF THE GLOBAL ENTREPRENEURSHIP SUMMER SCHOOL: AN INCENTIVE TO INTERNATIONAL EDUCATION. International Journal of Research GRANTHAALAYAH, 8(5), 230-240. https://doi.org/10.29121/granthaa layah.v8.i5.2020.195

Received Date: 16 May 2020

Accepted Date: 31 May 2020

Keywords: International Education Summer School Sustainability

\section{ABSTRACT}

This article seeks to bring a history of sustainability as a concept and to inform about global programs such as the Global Entrepreneurship Summer School about sustainability in a holistic approach to its three dimensions. It also addresses perceptions and results from the networking and international partnerships found throughout the event. It is about addressing the relationship between the events focused on social entrepreneurship and sustainability. This study aims is to share the impact of summer school programs as an incentive for education internationally, including the achievement of the Sustainable Development Education 4: Quality Education. The current work also verifies the incentive for the teaching of skills such as creativity, entrepreneurship, and fundraising in an international manner. From this experience and in the light of the international immersion with the contributions of the other participants and the enhancement promoted by the University of Western Cape. For the development of this work, we first analyze a history of sustainability and its three dimensions. Next, consumerism, blue economy, and social entrepreneurship are briefly discussed, and then the role of the Global Entrepreneurship Summer School is explored and elucidated the types of projects developed within the framework of the program. Finally, we relate the subjects to analyze the impact of such programs to enhance education and teaching.

\section{INTRODUCTION}

The word Sustainability became a concept in 1713 in the book Sylvicultura Oeconomica oder Naturmässige Anweisung zur Wilden Baum-Zuch of Hans Carl von Carlowitz (2017), who for 40 years was responsible for the administration of silver mining in Saxony.

(C) 2020 The Author(s). This is an open access article distributed under the terms of the Creative Commons Attribution License, which permits unrestricted use, distribution, and reproduction in any medium, provided the original author and source are credited. 
The Modern History of the concept of Sustainability begins in 1966 with the creation of the Club of Rome founded by Aurelio Peccei and Alexander King. Being a group of people who met to discuss matters related to politics, the international economy, the environment and sustainable development. This Club understood that the economic growth entered in route of conflict with Sustainability of the planet. The way in which economic growth and sustainability could be brought into harmony could only be achieved through international cooperation with the help of the State, business and civil society (BOSSELMANN, 2015).

Cruz and Glasenapp (2012), describe the moment the world lived in the second half of the 20th century:

The appropriation and transformation of nature "as the world's ability of reducing someone to the condition of object" led humanity to environmental problems, emerges as a "crisis of civilization", above all, of (i) modern (Western) scientific rationality, which has become the destructive capacity of humanity, and which from the second half of the twentieth century became not only profound but also irreversible, impossible to return to and respond to the challenges of technical civilization dependent on mineral and energy resources, thus provoking the very crisis of modernity and its paradigms.

Sweden and the Nordic countries suffered from constant acid rain in 1968. It therefore proposed to the United Nations Economic and Social Council (Ecosoc) a world conference, which would make possible an international agreement, in order to reduce the emission of gases responsible for acid rain (NASCIMENTO, 2012).

The result of Sweden's request was, in 1972, the United Nations Conference on the Human Environment, known as the Stockholm Conference. This was the first meeting of heads of state organized by the UN to address issues of degradation of the Environment. 113 countries and 400 governmental and non-governmental institutions participated in the conference.

It is noteworthy that a number of European countries and the United States of America participated in this conference, which were considered to be developed, but presented several environmental problems because they adopted an economic model that caused a lot of pollution and degradation of natural resources. And also because they use a great amount of natural resources and use them without any concern for the environment. On the other hand, the poor countries participated by living with problems related to hunger and poverty (SERRÃO, ALMEIDA, CARESTIATO, 2012).

At that meeting the Stockholm Declaration was produced (UN, 2018a). With 26 principles to be followed by its signatories. Here, three principles are highlighted:

Principle 3 - The capacity of the earth to produce vital renewable resources must be maintained and, wherever practicable, restored or improved

Principle 5 - The non-renewable resources of the earth must be employed in such a way as to guard against the danger of their future exhaustion and to ensure that benefits from such employment are shared by all mankind

Principle 13 - In order to achieve a more rational management of resources and thus to improve the environment, States should adopt an integrated and coordinated approach to their development planning so as to ensure that development is compatible with the need to protect and improve environment for the benefit of their population

The principles described above are all related to common land use. Another important issue highlighted in these principles is the finiteness of resources and the rational use of land resources. This preoccupation has already been demonstrated since the eighteenth century, by Hans Carl von Carlowitz (2017).

The Stockholm Declaration produced the first document, which recognizes a quality Environment for humans, thus leaving the world a better place for humankind. This statement still had the role of being the first moment in which the population was tried to raise awareness of problems related to disorderly growth, pollution and overexploitation of natural resources.

In 1972, the Club of Rome published the limits to growth: A report for the club of Rome's project the predicament of mankind (MEADOWS, 1972). The book begins by commenting that the growth of the world's population combined with industrialization and mass food production will increase pollution, leading to the depletion of natural reserves in the hundred years after its publication. The result would be a collapse, given that people would run out of food and live in a highly polluted environment.

To change this prediction, the work suggests that a condition of ecological and economic stability must be established through Sustainability. The possible way to achieve this stabilization would be through controlling population growth and controlling capital, using only the necessary natural resources to survive on Earth. 
In the 1970s, there were still two conventions on the Environment: Paris, which dealt with an integrated planning policy compatible with the protection of the Environment, and the 1978 Kuwait Convention, which called for integrated management to achieve environmental and development goals harmoniously (BOSSELMANN, 2015).

In December 1983, the UN General Assembly, through resolution 38/161, established a special commission to prepare a report on the Environment and the global problem by the year 2000. The report should also contain strategies and proposals for the sustainable development. This commission was named World Commission on Environment and Development (WCED) (UN, 2018c).

Participating in this commission were members from 21 nations with several from the South, having as main concerns the environmental degradation and the discrepancies of economic and social development between "Northern and Southern Hemisphere". According to Dr. Danielle Regina Ulrich, it is important to consider that

In the post-World War II period, the dynamics of North-South cooperation would be marked by the inauguration speech of the President of the United States, Harry S. Truman. Of a profoundly dualistic character, the aforementioned discourse would divide the world between, on the one hand, the countries classified as "developed" and, on the other, those classified by it as "underdeveloped", leaving the countries of the "North", rich and "developed ", To bring to the countries of the" South", poor and underdeveloped, the wonders of scientific advancement and technical and industrial progress, conquered by them. In 1987, this commission published the Brundtland Report through a document entitled Our Common Future, which pointed out the incompatibility between current production and consumption patterns and the standards of sustainable development (ULLRICH, 2014, p. 23). ${ }^{1}$

The report criticized the accelerated pace of expansion and scale of impacts on the environment of the current development model. The document presents a series of measures that countries should take to promote sustainable development, such as:

- limit population growth;

- meet the basic needs of the population (housing, health, school);

- controlling the disorderly growth of cities;

- guarantee people the basic resources (water, energy, food);

- preserving ecosystems and biodiversity;

- increase industrialization in underdeveloped countries, reduce non-renewable energy consumption. (UN, 2018d)

It also states in the report that countries should implement programs for sustainable development with the following measures:

- to use new types of less polluting materials with less waste;

- reduce the consumption of chemicals in food production;

- rationalize water and food consumption;

- recycle as much material as possible;

- seek new sources of energy, especially renewables;

- distribute residential areas and industrial zones. (UN, 2018d)

On this document, Cruz (2012) states that "there is a clear concern about the limits of natural assets and the need to ensure adequate conditions of a dignified life for future generations".

1 “No período pós-Segunda Guerra Mundial, a dinâmica da cooperação Norte-Sul seria balizada pelo discurso de posse do presidente dos Estados Unidos, Harry S. Truman. De caráter profundamente dualista, o referido discurso dividiria o mundo entre, de um lado, os países auto classificados de "desenvolvidos" e, de outro, os por ele classificados de "subdesenvolvidos", cabendo aos países do "Norte", ricos e "desenvolvidos", levar aos países do "Sul", pobres e subdesenvolvidos, as maravilhas do avanço científico e do progresso técnico e industrial, por eles conquistados. Em 1987, essa comissão publicou o Relatório Brundtland através de um documento intitulado Nosso Futuro Comum, que apontava a incompatibilidade entre os padrões atuais de produção e consumo e os padrões de desenvolvimento sustentável." ULLRICH, Danielle Regina. A construção de saberes no campo da cooperação internacional sul-sul à luz dos postulados e princípios da gestão social. Tese (Doutorado em Administração) - Universidade Federal do Rio Grande do SUL. Porto Alegre, 2014. p. 23. 
It is the Brundtland Report that is dedicated to the discussions on the difference between Growth and Development and also seeks to align the concepts of Development and Sustainability. The document mentions that development is the need of the population and Sustainability is the ability of the Environment to absorb this need (BOSSELMANN, 2015).

In 1992, the United Nations Conference on Environment and Development, also known as ECO 92, Rio de Janeiro and Rio de Janeiro Conference, took place in Rio de Janeiro, Brazil. organized civil society. In this event, we sought to "reconcile economic development with the provision and conservation of the Environment" (FEIL, SCHREIBER, 2017).

During this conference, two documents were produced: Rio Declaration and Agenda 21. "Rio Declaration, which establishes international agreements to protect and respect the integrity of ecology and global development, starting with environmental management and Sustainable Development" and the 'Agenda 21' "focuses on the implementation of environmental programs and policies" (FEIL, SCHREIBER, 2017).

Agenda 21 was constituted in a document that brought the reflection of each country, or rather, each nation could act in the solutions of the socio-environmental problems. Governments, enterprises and non-governmental organizations (organized civil society) should be involved in this solution. The idea of Agenda 21 was to make all countries prepare a plan for Sustainable Development, thinking about social inclusion, urban and rural sustainability, preservation of natural resources and political ethics.

The organized Civil Society sought to make the Earth Charter feasible during the event in Rio de Janeiro as an alternative to the Declaration, which was being produced. It had ecology as its center and sought eradication of poverty, socio economic development, human rights and peace.

Between 1995 and 2000, 46 countries and more than 100,000 people participated in a wide-ranging debate to enable the Earth Charter, which was ratified on March 14, 2000. This document has as its principles: Respecting and caring for the community of life, Integrity ecological justice Social and economic justice Democracy, non-violence and peace (MINISTÉRIO DO MEIO AMBIENTE-BRASIL, 2018).

The declaration Carta da Terra was signed by over one thousand non-governmental organizations, who sent to the UN a request for the recommendation and approbation of the document by the organization (BOSSELMANN, 2015).

In September 2000, the UN published the Declaration of the Millennium with the Millennium Development Goals, which came to the Earth Charter. This statement aims to:

- eradicate extreme poverty and hunger;

- achieve universal primary education;

- promote gender equality and empower women;

- reduce child mortality; Improve maternal health;

- combating HIV/AIDS, malaria and other diseases;

- ensure environmental sustainability;

- to establish a global partnership for sustainable. (UN, 2018a)

The Millennium Declaration was based on the principle of respect for nature. It was also based on freedom, equality, solidarity, tolerance and shared responsibility, as fundamental values and sought a new ethic (BOSSELMANN, 2015).

In Johannesburg, in 2002, Rio +10 took place or the World Summit on Sustainable Development, a forum organized by the UN, whose main objective was to verify the progress of Agenda 21 in the countries.

The conference also focused on the annihilation of poverty and defined 2002 that Sustainable Development has a foundation of formation of three essential pillars Triple Bottom Line: Environmental, social and economic" (FEIL, SCHREIBER, 2017).

Finally, in 2012, the UN Conference on Sustainable Development (UNCSD) Rio+20 "focused on renewing the commitment on sustainable development formalized in several countries in previous conferences. From this conference came the document entitled The Future We Want, focusing mainly on the issues of the use of natural resources, and on social issues such as the lack of housing and homelessness" (FEIL, SCHREIBER, 2017). 
The History of Sustainability and The Case of The Global Entrepreneurship Summer School: An Incentive to International Education

\section{CONSUMERISM}

The mismatch between future demand and supply is crystallizing into one of the most complex and urgent issues policymakers will face in the 21st Century. Despite the challenges arising from these scarcities, they can be seen as opportunities when confronted in a comprehensive and proactive manner. There are a number of issues to consider when examining the issues of consumption and consumerism.

The production of commodities often requires the extraction and use of natural resources, such as wood, ore, fossil fuels, and water. To feed our growing world population, global food consumption consequently affects the environment through food-related energy consumption and waste, which is a large issue when talking about consumption. Still, recycling and reusing products is rare since most products simply end up in landfills or get burned. This will also lead us to talk about fair trade and the impact of a consumerist culture on our local economies.

Finally, with the consumption of goods and services comes the formation of gentrification processes as well which can severely affect poor communities for the benefits of the wealthiest social class.

With a growing population, there will be also a rising amount of goods that need to be produced to cover the demand of the 9.6 billion people that are expected to live on this planet by 2050 . This will also increase the demand for already constrained natural resources. If we don't change our consumption and production patterns, we will cause irreversible damage to our environment (UNITED NATIONS IN GHANA, 2018). When it comes to consumers, households consume 29 percent of the global energy and contribute to 21 percent of CO2 emissions (WORLD MEET SUMMIT, 2018).

Although the use of modern renewable energy, especially in high-income countries has grown in the past years (WORLD BANK - DATA, 2018), due to the population growth, the use of natural resources are not enough to supply the need of the enormously growing world population (especially in low income countries) in times of drastic resource scarcity.

Agriculture and the textile industry are a major part of the climate problem. The agriculture sector alone currently generates 19-29 percent of total GHG emissions. Without action, that percentage could rise substantially (UNITED NATIONS - STATISTICS DIVISION, 2018).

Environmentalists often consider population, technology and consumption as the three key drivers responsible for environmental pollution. However, consumption seems to get the least attention. One reason is that it may be the most difficult one to change; our consumption pattern is part of our everyday lives and changing it would require a massive cultural overhaul, not to mention severe economic dislocation (GLOBAL ISSUES, 2018).

Experiences from the last years have shown that the strategies to implement sustainable products and efficient energies are only slowly generating change in society. Consumption and consumerism are deeply integrated in cultural habits. Consumption habits also show the state of a nation. For example, the rising amount of middle-class citizens in Mexico believe that obesity is a symbol of good health and higher socioeconomic status (HINDAWI INTERNATIONAL JOURNAL OF POPULATION RESEARCH, 2018).

In China, which experienced a booming economy in the past years, consumption and abundance are a symbol of status. Chinese consumers represent 5.29 percent of the world consumer market and to offer guests extensive amounts of food is a sign of wealth. Thus, it is not surprising that China generates 17-18 million tons of food waste each year - enough to feed 30-50 million people (FUTURE DIRECTIONS INTERNATIONAL, 2018).

Germany's economy has been doing consistently well for many years and therefore, there is a trend to minimalism and sustainability. Many Germans recycle and their goal is to shut down all nuclear power plants and switch to green energy by 2022. At the same time, precisely through its strong economy, Germany is producing enormous amounts of trash (between 325 and 350 million tons each year) and Germans have their fair share in polluting the environment, e.g. through their love to cars (THE WASHIGTON POST, 2019).

The gap between rich and poor in South Africa is the highest worldwide. This is also reflected in the culture of consumerism. While the rich expect shops and services to be available anytime, the poor try to upcycle or even just secure electricity and water supplies for their townships (BBC NEWS, 2019).

Culture is deeply intertwined with our consumption patterns, which means it would require a massive cultural overhaul in order to change ingrained practices. 


\section{BLUE ECONOMY}

The blue economy is a model that proposes structural changes in the economy based on the functioning of ecosystems. The idea is to turn problems into opportunities to create possible solutions for human health, the environment and the pocket (NAIME, 2018).

Unfortunately, the green economy has not taken off. While it has made an impact on specific products in niche markets, it has yet to shape our entire economic system. While the world market for green products reached an estimated $\$ 635$ billion industry by 2010 , it represents less than $1 \%$ of world annual output. The main challenge is that this green approach requires companies to invest more and consumers to pay more. This is a valid and justified strategy when the world economy is expanding and unemployment is decreasing, or when the main actors on the market are flush with financial resources (JAPAN SPOTLIGHT • JANUARY / FEBRUARY 2011, 2018).

\section{SOCIAL ENTREPRENEURSHIP}

Social entrepreneurship is a term that means a lucrative business and that at the same time brings development to society. Social enterprises, other than NGOs or joint ventures, use market mechanisms to seek solutions to social problems through their core business.

\section{GLOBAL ENTREPRENEURSHIP SUMMER SCHOOL}

A summer school is a program generally sponsored by a school or a private company, that provides lessons and activities during the summer vacation. Participation in summer schools has been shown to have substantial beneficial effects on educational progress. The concept of summer schools has spread fast throughout the globe and now high impact students are bringing forth changemaking as a result of their participation in such programs.

The Global Entrepreneurship Summer School (GESS) is a seven-day program where 140 university students come together in Munich, Mexico City, Shanghai, and Cape Town to develop entrepreneurial solutions that meet the world's biggest challenges. In the spirit of promoting "billion-dollar projects to foster societal change", GESS works on the UN Sustainable Development Goals aiming to empower students to become young responsible leaders who create positive change in our society.

The vision of the Global Entrepreneurship Summer School is based on the idea of "Billion Dollar Projects to Foster Societal Change": the program encourages and connects top students from all over the world to challenge society's biggest problems with even bigger ideas - and an entrepreneurial approach.

The Global Entrepreneurship Summer School (GESS) is a program of the Social Entrepreneurship Akademie based in Munich, Germany, organized in cooperation with six leading university-based entrepreneurship centers in Munich, Shanghai, Mexico City and Cape Town.

Since 2008 SEA's Summer School program was known as EIISS (Entrepreneurial Impact International Summer School), in the 5th year of existence it was rebranded to Global Entrepreneurship Summer School. The Global Entrepreneurship Summer School is part of the UN Decade of Education for Sustainable Development (DESD). The goals of the Decade are to provide opportunities for refining and promoting the vision of and transition to sustainable development through all forms of education. The Global Entrepreneurship Summer School fosters the important role of education in sustainable development and connects ambitious, entrepreneurial students from all over the world.

In 2018 for the first time, GESS has taken place on four continents in four different cities. Mexico City, Cape Town, Shanghai and Munich hosted this year's edition about consumption. Sustainable consumption and production are some of the major challenges of our time. Entrepreneurial solutions from innovative, creative and enthusiastic students like you are needed to solve the issues surrounding the challenges of consumerism in a rapidly growing society. During the course of one week, students from all over the world worked on the following topics: Environment, Culture, Production, Global Food Consumption and Waste.

Gathering people from different parts of the planet has benefits shown by research findings, for example, that country of origin influences the work behavior of second-generation immigrants and the organization of multinational corporations' local plants, but are a more direct test of the role that culture plays in economic choices, and also about how one endeavors in entrepreneurship. 
The History of Sustainability and The Case of The Global Entrepreneurship Summer School: An Incentive to International Education

\section{GESS CAPE TOWN}

Our host in CapeTown was LifeCo UnLtd, which is a social enterprise, established over 2 decades ago during the times of segregation and marginalization in South Africa. The enterprise focuses on 2 key elements: entrepreneurial education for youth, and entrepreneur development. It finds, funds and invests in emerging social entrepreneurs to expand their impact and access to market.

It facilitates programs focused on critical thinking, capital and entrepreneurial practice to schools and universities and is an active advocate for social impact - the organization is strategically placed to guide policy direction in South Africa and is a global influencer in the sector. LifeCo UnLtd is also a global advocate for impact enterprise and impact investment and a founding member of the Global Social Entrepreneurship Network (GSEN). The partnership with LifeCo bundles and introduces eight South African Universities to the GESS initiative significantly increasing GESS's University presence. This year, GESS Cape Town was located at the University of the Western Cape.

The University of the Western Cape has a history of creative struggle against oppression, discrimination and disadvantage. Among academic institutions it has been in the vanguard of South Africa's historic change, playing a distinctive academic role in helping to build an equitable and dynamic nation. UWC's key concerns with access, equity and quality in higher education arise from extensive practical engagement in helping the historically marginalized participate fully in the life of the nation. Established in 1959, since well before the end of apartheid in South Africa in 1994, it has been an integrated and multiracial institution. Nowadays the institution has an estimate of 22,000 students.

There were about 35 students from about 10 different countries. The acceptance rate of the 2018 program in Cape Town was 4,68\%. The group analyzed in this article had participants from 4 different nations: China, Switzerland, Germany and South Africa.

\section{CULTURE TEAM AND THE SEED OF CHANGE PROJECT}

Professor Stephen Chan said "There is too much short-term thinking in Africa" (THE ZIMBABWE SITUATION, 2019), along with that statement and a field research in the townships of Khayelitsha and Philippi in the city of Cape Town leads us to believe that this issue could be addressed within the communities by helping the locals to see clearly the benefits of a long-term thinking.

"Seed for Change" is trying to shift short-term thinking in South Africa by working with school children and giving them a stevia plant to grow.

The plant is currently not commercially grown in Southern Africa, with the main international producers being China and India. South Africa also has experienced growing obesity, the sugar sweetened beverages are targeted as the main cause of this problem. Tax on sugary drinks was signed into law. Since 2 April 2018, South Africans are paying approximately $10 \%$ of a can of Coca Cola in 'sugar tax', for example.

The idea is to implant a plant that can be harvested continuously and is also a healthier option to sugar. The children learn patience and long-term thinking by harvesting at particular times, and particular amounts, in order to keep the plant growing and producing.

The accompanying teaching app helps the teacher see the process through by guiding harvesting time and incorporating little tutorials on long-term thinking.

The tendency to consume quantity over quality will be subverted by realizing just a little stevia has a lot of sweetness. And a little bit of patience has a big long-term reward.

\section{THE IMPACT: ENHANCING EDUCATION AND TEACHING}

To reach the conclusion of this text a questionnaire was sent to the GESS alumni with the following questions:

1.- What were the immediate results of GESS in your personal life?

1.1.- I started thinking about my actions in the world and sustainability.

1.2.- I started considering in my actions society, economy and nature.

1.3.- I started (or continued) a social business.

International Journal of Research -GRANTHAALAYAH 
1.4.- I started (or continued) to engage in international education events.

The answers of the participants of the survey generated the following graphic:

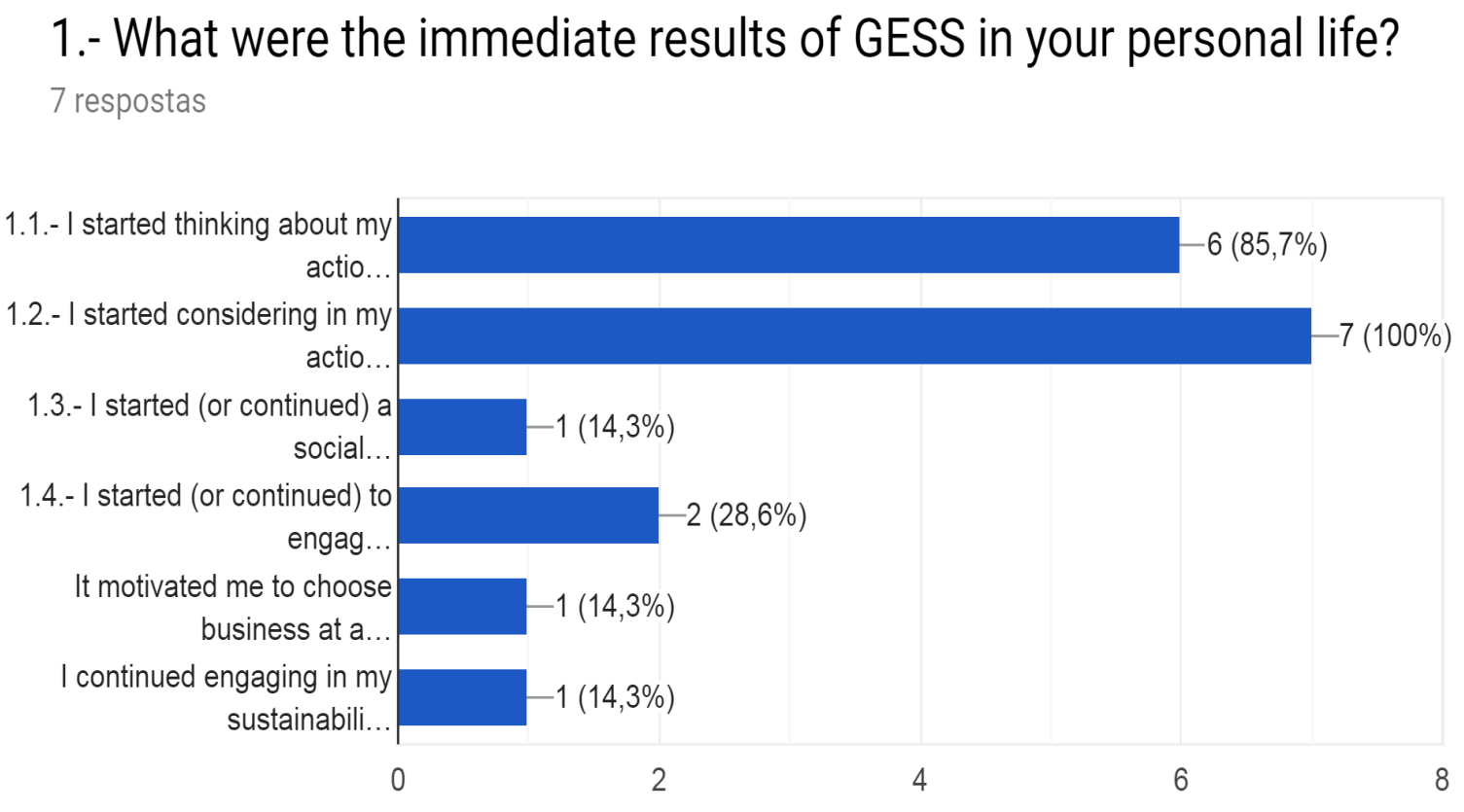

In answering the survey it was also possible to include a brief text about the experience of GESS. The following answers were recorded: "I am Shivi from India. I think GESS was one of the best experiences of my life till now. So many things, experiences and people. I learned three main things: 1 . Material life is less important to me now. 2 . I try to measure impact in whatever I do. 3. I always try to find solutions to the problems around me." Erika, from Mexico: "I discovered that even if you have different culture or nationality, we want the same, a better world for everyone. I started to reduce my impact in the planet by trying to stop using one use plastics. And share with my example to others how important our actions are." Alice, from Brazil recorded: "Definitely the change of mindset. Nowadays I'm much more critic about sustainability and the consequences of my actions."

One anonymous participant of the survey mentioned: "One of the principles we learned at GESS has had a particular long-term effect - the thought to "sit through the uncomfortable". I am active with regards to social and environmental sustainability in my work and personal life, and I have encountered several situations were this thought has helped me to stay focused and committed. There will always be challenges, conflicts and contradictions in social or environmental activism. This principle is of great help to keep both an open mind and the energy to move forward." Yousra from Morocco: "Besides the amazing outcomes of the experience this program helped me to stand out from the crowd when i applied for a job. I started to think of different ways to solve an issue, I became more conscious about my daily choices when it comes to food consumption."

Mariam El-Etreby from Egypt: "After hearing about circular economy in one of GESS sessions, I took several courses about it, and then $\mathrm{i}$ was recommended to work as a coordinator for a social enterprise on an entrepreneurship and sustainability program for Egyptian youth. GESS was an eye-opening experience. It redirects my thoughts towards sustainability and that the minimum effort matter, it's a ripple effect."

\section{CONCLUSIONS AND RECOMMENDATIONS}

It was noted that the necessity for sustainability led to the creation of a new mindset and even new legislation on the subject. That focus also created a new need in the educational scenario. The Global Entrepreneurship Summer School showed to be an answer to the concerns of young entrepreneurs. 
The History of Sustainability and The Case of The Global Entrepreneurship Summer School: An Incentive to International Education

In the crossroads where sustainability and international education meet it is well noticed that events such as summer schools do increase a desire of the participants to continue engaging on educational activities that allow a student exchange.

\section{SOURCES OF FUNDING}

None.

\section{CONFLICT OF INTEREST}

None.

\section{ACKNOWLEDGMENT}

None.

\section{REFERENCES}

[1] BBC News. South Africa elections: is the gap between rich and poor widening?. Available in: https://www.bbc.com/news/world-africa-48023890 Access on: may. /16/2019.

[2] Bosselmann, K. 0 princípio da sustentabilidade: Transformando direito e governança. Translation: Phillip Gil França. São Paulo: Revista dos Tribunais, 2015, 60-60. Original Title: The principle of sustainability: transformind law and governasse.

[3] Carlowitz, H. C. Sylvicultura oeconomica. Charleston: Andesite Press, 2017.

[4] Consumers in the Digital Age Identity and Consumption in Second Life. Corvinus University of Budapest. Available in: http://phd.lib.uni-corvinus.hu/796/3/nagy_peter_ten.pdf Access on: dec./13/2018.

[5] Cruz, P. M. Globalização, transnacionalidade e sustentabilidade Special participation: Gabriel Real Ferrer; Organization and Review: Lucas de Melo Prado. Itajaí: UNIVALI, 2012. Available in: http://www.univali.br/ppcj/ebook.Zenildo

[6] Cruz, P. M.; Glasenapp, M. C. Governança e sustentabilidade: constituindo novos paradigmas na pósmodernidade. Revista Direitos Culturais, Santo Angelo, vol. 8, no. 17, january/april 2014, 191-208.

[7] Europe PMC. Making the most of summer school: a meta-analytic and narrative review. Available in: http://europepmc.org/abstract/med/12467098/reload=2;jsessionid=t0snnetzjb0jxkimt8i0.22 Access on apr./18/2019.

[8] Feil, A. A.; Schreiber, D. Sustentabilidade e desenvolvimento sustentável: desvendando as sobreposições e alcances de seus significados. Cadernos Ebape.br, Rio de janeiro, vol. 15, no. 3, july/september 2017, 667-681.

[9] Foodstuff South Africa. Pioneering Project To Develop A South African Stevia. Avaliable in: https://www.foodstuffsa.co.za/pioneering-project-to-develop-a-south-african-stevia/ Access on: jan./09/2020.

[10] Future Directions International. The wasteful dragon: food loss and waste in China. Avaliable in: http://www.futuredirections.org.au/publication/wasteful-dragon-food-loss-waste-china/ Access on: oct./02/2018.

[11] Garcia, F. P.; Ribeiro, S. Economia azul e segurança marítima: 0 caso de Portugal. Relações Internacionais, Lisboa, no. 57, march 2018, 39-58. Available in: http://www.scielo.mec.pt/scielo.php?script=sci_arttext\&pid=S1645-91992018000100004\&lng=pt\&nrm=iso Access on: may/16/2019.

[12] Global Issues. Effects of consumerism. Available in: http://www.globalissues.org/article/238/effects-ofconsumerism Access on: oct./02/2018.

[13] Governo do Brasil: Cidadania e Justiça. Empreendedorismo social gera lucro e desenvolvimento. Available em: http://www.brasil.gov.br/cidadania-e-justica/2012/02/empreendedorismo-social-gera-lucro-edesenvolvimento Access on: dec./13/2018. 
[14] Harvard Business School Publishing. Research: Where a Founder Is from Affects How They Structure Their Company. Available in: https://hbr.org/2019/09/research-where-a-founder-is-from-affects-how-theystructure-their-company?utm_source=linkedin\&utm_campaign=hbr\&utm_medium=social Access in: sept. /06/2019.

[15] Hindawi - International Journal of Population Research. Risk factors for overweight and obesity among mexican children in new york. Available in: https://www.hindawi.com/journals/ijpr/2016/2420167/3 Access on: oct./02/2018

[16] Japan Spotlight January / February 2011. The blue economy. Available in: https://www.jef.or.jp/journal/pdf/175th_cover04.pdf Access on: oct./02/2018.

[17] Jstor. The effect of interest rates on aggregate consumption. Available in: https://www.jstor.org/stable/1818404?casa_token=-

h4igqcnereaaaaa:zf302okp40anzlagfjhbl6y8fc5pkqen9jlvneaajokyah74gwvd6qnlwjkkn8nzordkqz2bvxs4d7i pawheao1avkkvk4fpheshhqi7sppnkamhprwy\&seq=1\#metadata_info_tab_contents Access on: apr./18/2019.

[18] Meadows, D. L., et al. The limits to growth: A report for the club of Rome's project the predicament of mankind. 5 ed. New York: Universe Books, 1972.

[19] Medium. O que ter participado do Global Enterpreneur Summer School me ensinou? Available in: https://medium.com/@alicesantanna/o-que-ter-participado-do-global-enterpreneur-summer-school-meensinou-e448a4a54f3a Access on: jan./09/2020.

[20] Ministério do Meio Ambiente-Brasil. Carta da Terra. Available in http://www.mma.gov.br/estruturas/agenda21/_arquivos/cartadaterrahistoria2105.pdf Access on: jul./01/2018.

[21] Naime, R. Economia azul. Available in: https://www.ecodebate.com.br/2019/04/04/economia-azul-artigode-roberto-naime/ Access on: oct./02/2018.

[22] Nascimento, E. P. Trajetória da sustentabilidade: do ambiental ao social, do social ao econômico. Estudos Avançados, São Paulo, vol. 26, no. 74, january 2012, 51-64. Available in: http://www.revistas.usp.br/eav/article/view/10624. Access on: jul./03/2018.

[23] Organics News Brasil. O conceito da economia azul. Available in https://organicsnewsbrasil.com.br/meioambiente/o-conceito-da-economia-azul/. Access on: oct/02/2018.

[24] Serrão, M.; Almeida, A.; Carestiato, A. Sustentabilidade: Uma questão de todos nós. Rio de Janeiro: Senac, 2012, 12.

[25] The Washigton Post. Germans love their cars. They also love the environment. A diesel ban is forcing them to choose. Available in: https://www.washingtonpost.com/world/europe/germans-love-their-cars-they-alsolove-the-environment-a-diesel-ban-is-forcing-them-to-choose/2018/04/18/6868777c-3bfc-11e8-955b7d2e19b79966_story.html Access on: may/16/2019

[26] The Zimbabwe Situation. There's too much short-term thinking in Africa - Prof. Chan. Available in: https://www.zimbabwesituation.com/old/apr11_2005.html\#link29. Access on: apr./18/2019.

[27] Ullrich, D. R. A construção de saberes no campo da cooperação internacional sul-sul à luz dos postulados e princípios da gestão social. Tese (Doutorado em Administração) - Universidade Federal do Rio Grande do SUL. Porto Alegre, 2014.

[28] UN. Declaration of the united nations conference on the human environment. Available in: http://www.undocuments.net/unchedec.htm Access on: jun./29/2018.a

[29] UN. Millenium declaration. Available in: http://www.un.org/en/development/devagenda/millennium.shtml Access on: jul./01/2018.b

[30] UN. Sustainable development knowledge platform. Available in: https://sustainabledevelopment.un.org/milestones/wced Access on: jul/01/2018.c

[31] UN. Our common future. Available in: http://www.un-documents.net/our-common-future.pdf Access on: jul./01/2018. d

[32] United Nations - Statistics Division. Goal 7: ensure access to affordable, reliable, sustainable and modern energy for all. Available in: https://unstats.un.org/sdgs/report/2016/goal-07/ Access on: oct./02/2018.

[33] United Nations in Ghana. Goal 12: ensure sustainable consumption and production patterns. Available in: http://gh.one.un.org/content/unct/ghana/en/home/global-agenda-in-ghana/sustainable-developmentgoals/sdg-12-responsible-consumption-production.html Access on: oct./02/2018. 
[34] University of the Western Cape. Global Entrepreneurship Summer School 2018: Billion Dollar Projects to Foster Societal Change. Available in: https://www.uwc.ac.za/News/Pages/Global-Entrepreneurship-SummerSchool-2018-Billion-Dollar-Projects-to-Foster-Societal-Change.aspx Access on: jan/09/2020.

[35] World Bank - Data. Renewable energy consumption (\% of total final energy consumption). Available in: https://data.worldbank.org/indicator/eg.fec.rnew.zs Access on: oct./02/2018.

[36] World Bank. Climate-smart agriculture. Available in http://www.worldbank.org/en/topic/climate-smartagriculture Access on: oct./02/2018

[37] World Health Organization - Who. South African: Experience in Introducing Sugar taxation. Available in: https://www.who.int/nutrition/events/2018-fpgh-workshop-nutrition-against-ncd-16nov-presentationLindiweMakubalo-SouthAfrica.pdf Access on: jan./09/2020.

[38] World Meet Summit. Ensuring sustainable consumption and production patterns. Available in: https://worldmeetsummit.com/ensuring-sustainable-consumption-and-production-patterns/ Access on: oct./02/2018. 